\title{
INCAPACITY OF PARTIES AND INVALIDITY OF ARBITRATION AGREEMENT AS GROUNDS FOR REFUSING RECOGNITION AND ENFORCEMENT IN KUWAIT Saad Badah ${ }^{1}$
}

\author{
Saad Badah \\ ${ }^{1}$ Law School, Brunel University, London, UK . \\ Correspondence: Saad Badah, Law School, Brunel University - London, UK. Tel: \\ 0096599200747: \\ E-mail:SaadAHJ.Badah@brunel.ac.uk,sa3d51@ hotmail.com
}

\begin{abstract}
Arbitration agreement is one of the widely discussed laws of contract in law. Each and every country has specific rules and regulation which government had rules which govern the arbitration contract between the citizens and between the nation and other nations. Kuwait is one of such countries and it has faces a lot of challenges what it comes to arbitration law and sharia law until the time when New York Convention was incorporated and ratified in the process of administering justice in the Kuwait. The enforcement of the awards specifically has brought challenges until the NYC provided the grounds under which the enforcement of the awards may be rejected. The main objective of this paper is to discuss whether Incapacity of Parties and Invalidity of Arbitration Agreement as sufficient Grounds for Refusing Recognition and Enforcement in Kuwait. The paper is divided into five sections with first section giving introduction and definition of what is arbitration, the second part discusses the finality of the awards, thirdly it discuses the finality of the awards, fourthly the paper discuses the rejection of enforcement due to invalidity and incapacity and lastly the paper discusses the position of NYC position on the sufficiency of invalidity and incapacity as enough proof for non-enforcement and recognition of arbitration agreement as a result of invalidity and incapacity be for concludes with conclusion.
\end{abstract}

\section{Key words: Incapacity, Parties, Arbitration, Agreement}

\section{Introduction}

Arbitration is one of the many means of finding conflict resolution out of court. It is similar to reconciliation but more formal than reconciliation ${ }^{l}$. The different between arbitration and reconciliation also exist in the process through which they pass since arbitration does not give room for continuous collective bargaining and negations while reconciliation gives room for that ${ }^{2}$.

There are several types of Arbitration. They include;

I. Arbitration based on the international laws

II. Arbitration based on the national laws

III. Jurisdictional arbitration

IV. Arbitration between two conflicting parties

Most arbitration formation and their validity are determined by the principles of Lex

\footnotetext{
1 (2005)Barraclough, A., and Waincymer, J., Mandatory Rules of Law In International Commercial Arbitration, MELB.J.Int'1 L. 6 at 210-211

2 (2011)Al-Nowaser, K., A legal review on the principle of "The contract is the law of contractors", Aleqt.com, at http://www.aleqt.com/2011/11/06/article_596219.html (last accessed on Feb 28th 2014)
} 


\section{Saad Badah}

contractus (property law) of the arbitration contract agreement ${ }^{3}$. In the year 2000, the commercial Arbitration center of the Kuwait was set up and the Kuwait parliament ratified it in the same year with many treaties of bilateral trade within the Middle East and all over the world, the treaties in them give room for settlement through arbitration process concerning disputes which arises as a result of those treaties ${ }^{4}$. The Kuwait laws which are governing arbitration agreement mainly apply to procedures for domestic arbitration and also concerning the enforcement of foreign awards. Under the arbitration law of Kuwait, parties of arbitration process may decide to determine the rules they are going to use in the arbitration proceeding concerning them ${ }^{5}$. The clause model reads,

"Any dispute whatsoever which may arise out of this contract, its execution or its cancellation is to be referred to arbitration in accordance with the conditions stipulated in the Reconciliation and Arbitration System of the Kuwait Chamber of Commerce and Industry"”.

The main body or center for arbitration in Kuwait is the Commercial Arbitration Center of the Kuwait Chamber of commerce and Industry (KCAC) and expert from different professional bodies and societies also help in arbitration process ${ }^{7}$. There are also rules which are governing optional arbitration in Kuwait and they are mainly contained in the code of Civil and Commercial Procedures (CCCP). It was promulgated by law 38 of 1980 and later amended in 2002 by law 36 in article 173 to 188 of Kuwait by law ${ }^{8}$.

\section{Finality of the Awards}

In most Arabs countries and Saudi Arabia, Article 19 of the arbitration code do allows the parties to the contract to challenge arbitration award within 15 days of the decision and this is contrary to the post modernism arbitration rules. International bodies have a clear principle which does not allow the arbitration decisions to be appealable more so on the basis of their substance but give alternatives grounds under which they can be appealed ${ }^{9}$. These grounds are procedural in nature.

In Kuwait, the law allows the parties to freely negotiate and if appropriate include the option of arbitration to their own terms and condition ${ }^{10}$. The length of time taken to set up a tribunal usually depends on the agreement of the parties involve ${ }^{11}$. Arbitration award can be appealed in court and be nullified, they include;

I. In case there is lack of a valid agreement between the parties

II. In situations where there is procedural irregularities

III. In situations where arbitral tribunal instituted exceeded in given Authority and mandate

IV. The subject matter under contention is beyond arbitration settlement.

Kuwait government ratified the New York Arbitration Act of 1996

Section 103 of the 1996 Act on arbitration gives room and provides recognition of enforcement of New York convention award shall not be refused except on certain specific

\footnotetext{
${ }^{3}$ (2011) Gandhi, P., Delhi High Court: The public policy ground for resisting enforcement of foreign awards must be interpreted narrowly, Arbitration.practicallaw.com,

${ }^{4}$ ( 2006)Komninos, A., Recent Development in International Arbitration Around The World, 2 White and Case Int'l Newsletter 19 at 5-6

5 (2001)Park, Arbitration of International Contract Disputes, supra note 64, at 1787

${ }^{6}$ (1986) Nicholas Ulmer, Drafting the International Arbitration Clause, 20 Int'1 Law 1335, at 1342-43

7 (1990) International Standard Elec. Corp. v. Bridas Sociedad Anonima Petrolera Industrial y Comercial, 745 F. Supp. 172, 176-78 (S.D.N.Y. 1990

${ }^{8}$ (2003) Bowman Routledge, On the Importance of Institutions, Review of Arbitral Awards for Legal Errors, 19(2) J Int'1 Arb 81 (2002).

9 (1994) Roy, K., The New York Convention and Saudi Arabia: Can a Country Use the Public Policy Defence to Refuse Enforcement of Non-Domestic Arbitral Awards, Fordham International Law Journal 18 at 921

${ }^{10}(1980)$ Kuwaiti Arbitration Code

${ }^{11}$ (1980)Kuwaiti Arbitration Code
} 
grounds which are listed in subsection 103(2-4). ${ }^{12}$ Section 103 subsection 2 of the Act provides that "Recognition and enforcement of the arbitration award may refused in case the person against whom that award is given proves any of the following"

I. That one party of arbitration agreement was under some incapacity

II. That the arbitration agreement was not valid under the Kuwait law in which the decision was made

The New York arbitration Act recognizes that incase a party to an arbitration agreement was duly presented or incapacity in any manner, under sub article 7 of the Act, then that is sufficient ground for not enforcing the agreement ${ }^{13}$.

There are circumstances under which appeals on the grounds of merits are also accepted, though this is quite different in Kuwait which also uses Sheria law as well where the ground of the challenges are based on the procedural flawlessness and the appeals on the merits are accepted only if both the parties involved expressly do so before the occurrence of the case $\mathrm{e}^{14}$.

The best known case on this is the Emaar case of 2009 the grievances board reversed an award which had been issued in favor of Emaar one of the Dubai based company against the Saudi company known as Jawadel International ${ }^{15}$. In there decision, the competent court had to review their decision based on the substance of conflict ${ }^{16}$.

\section{Rejection of Award under incapacity and invalidity}

The New York agreements states that lack of capacity to submit to arbitration constitutes invalidity of an arbitration agreement hence sufficient grounds for lack of enforcement. It is generally accepted in Kuwait and under the convention that the willingness of two or more parties who have no capacity or are not legally entitled to have obligations has no legal effect ${ }^{17}$. Capacity is one of essentials of any legal agreement and arbitration agreements are not exceptional to these rules and rules and regulations hence such agreements are void. The invalidity of the arbitration agreement due to incapacity and lack of enforcement may be declared in the following stages;

I. Under situations where discussion on the enforceability of the arbitration agreement

Under sub Article 8.1 of model Law states, "A court before which an action is brought in a matter which is a subject of an arbitration agreement shall, if a party so request should be during or before submission of his initial statement on the substance of the dispute, refers to the parties to arbitration unless it finds that the agreement is null and void, incapable or inoperative of being done"

Article II sub-Article 3 of the New York Convention Act states: "The court of contracting state, when seized of an action of issues in respect of which the parties have made an agreement within the meaning of this article, shall at the request of one of the parties to the agreement, refers to the parties to the arbitration, unless it finds that the said agreement is void, null, incapable or inoperative of being performed ${ }^{18}$,

These two quotes show that incapability of the parties to the arbitration agreement is enough grounds for refusing enforcement of arbitration awards. A decided case on invalidity

\footnotetext{
12 (1980) Kuwaiti Civil and Commercial Procedural law

13 (1958)The New York Convention on the recognition and enforcement of foreign awards of 1958

${ }^{14}$ ( 2002)The International Chamber of Commerce Arbitration rules

15 ( 2009) Karam, S., Emaar Properties to appeal lawsuit ruling, Arabianbusiness.com, (2009) at http://www.arabianbusiness.com/emaar-properties-appeal-lawsuit-ruling-13830.html

${ }^{16}(2009)$ Redfren, A. and Hunter, M., International Arbitration (Fifth ed) (Oxford, UK: Oxford University Press, 2009)

${ }^{17}$ Commercial Arbitration Centre of the Kuwait Chamber of Commerce and Industry (KCAC)

${ }^{18}$ (1990)The NYC Art.3
} 


\section{Saad Badah}

of arbitration agreement which had been rejected is the case of In re Aramco Services Company.

Facts: The Saudi oil company Aramco had entered into contract with Dyn Corp and the arbitration clause was included in the agreement. The arbitration agreements stated that SAC should be included in the agreement ${ }^{19}$.

Decision: Subsequently, the appeal court accepted the Aramco request and declared that the trial court lacked the capacity and authority to appoint arbitrator after the court had appointed two Muslims arbitrators t preside over the tribunal $l^{20}$.

From the above case, therefore it can be concluded that incapacity and invalidity of the arbitration agreements are enough grounds of not enforcing arbitration awards.

II. The second instance is when the arbitration awards had been challenged by one of the party in set aside proceedings.

Article 34 of the model law sub-section two states that: "An arbitral award may be set a side by a competent court specified under article six if; The party making the applications furnishes the proof that; a party to the arbitration agreement referred to in subArticle 7 was under some incapacity; or the said agreement is not valid under the law to which the parties have subjected it and or, failing any indication thereon, under the of the State..."

III. Lastly in situations where enforceability of the and recognition of the arbitral awards is claimed by a party to the agreement,;

Under Article 36 of the model law states that: "Recognition and enforceability of an arbitral award irrespective of the country in the agreement was made, may be refused on condition that; at the request of the party against whom it is invoked, in case the party furnishes to the competent court where enforcement or recognition is sought proofs that; $(i) A$ party to the arbitration agreement referred to in article 7 of the Act was under some incapacity or in other words, the said agreement is not valid under the law to which the parties have subjected it or, failing any indication thereon, under the law of the country where the law was made ${ }^{2 l}$ ",

Article 5 of the New York Convention subjection 1 states that: "Recognition and enforcement of the award may be refused, at the request of the party against whom it is invoked, only if the party furnishes to the competent court where the enforcement and recognition is sought, proof that (a) the parties to the agreement referred to in the article (ii) of the Act, under the law is applicable to them, under incapacity, or the said agreement is not valid under the law to which the parties have subjected it or failing any indication thereon, under the law of the country it was ${ }^{22}$ made... ${ }^{23}$."

Both the model law and New York Convention law of which Kuwait government is a party two, recognizes that incapacity is enough grounds for rejecting arbitration awards and the New York conventions goes further to establish the governing principles under which the concept of capacity to the arbitration principles should apply in something which is not present in the model law ${ }^{24}$.

Finding uniformity concerning the applicability of the law concerning capacity of individuals in the arbitration law has been a problem. It has majorly depends on the system of conflicts of law of the forum known as the arbitration agreement ${ }^{25}$. The criterion applicable

\footnotetext{
${ }^{19}$ ( 2010)In re Aramco Services Co., No. 01-09-00624-CV, (Tex. App. - Houston [1st], March 19, 2010)

${ }^{20}$ (2010)In re Aramco Services Co., No. 01-09-00624-CV, (Tex. App. - Houston [1st], March 19, 2010)

${ }^{21}$ The Implementing Regulations of the Saudi Arbitration Code Art. 3

${ }^{22}$ The NYC Art. IV

${ }^{23}$ Supra note 23 at p.97

${ }^{24}$ (2006)Komninos, A., Recent Development in International Arbitration Around The World, 2 White and Case Int'l Newsletter 19 at 5-6

${ }^{25}$ A regional code that includes all the Gulf Cooperation Council (GCC)
} 
and should prevail is that legal capacity should be governed by the personal law of individuals of each party to the agreement. So it goes without saying that incapacity to arbitration agreements are enough grounds for rejecting arbitration awards ${ }^{26}$.

The law normally contains some specific provisions on the capacity to an arbitration agreement. Normally a domestic arbitration like in Kuwait case, the most important think is whether the parties have the legal capacity to enter into the contract and in case they are not then; such arrangements are null and void ${ }^{27}$. In the international arena, problems related to legal capacity is a common thing mostly on the corporations concerning the individuals who are carrying out the arbitration agreement.

\section{The New York Convention and foreign Award enforcement in Kuwait}

Kuwait State is one of the countries which ratified the New York Convention and made reservation agreement regarding enforcement of the awards which are issued by the New York convention (NYC) contracting states ${ }^{28}$.

NYC also recognizes incapacity and invalidity of the arbitration agreements as sufficient grounds for not enforcing the awards ${ }^{29}$. The types of grounds for challenging the arbitration awards are less controversial compared to Sheria law used in Kuwait and other Arab countries since they are procedural irregularities. The NYC has given room to all contracting States to refuse recognition or enforcement when the result of either action that would lead to breaching of public policy. Countries like Syria and Kuwait on the other hand have adopted narrow approach concerning the interpreting of the convention on the public policy. ${ }^{30}$

\section{Conclusion}

In conclusion, there are several ways and grounds under which arbitration agreements may be rejected on other grounds apart from incapacity and invalidity. Just like any other contractual agreement, the parties to the contract must have the capacity to enter into the contract. One cannot enter into contract with minors and since most minors have no capacity to enter into contract. The contract must also be valid and in case of invalidity, the contract is deemed null and void. Due to growing importance of the arbitration system in Kuwait, it is continuously growing in Kuwait legislation under law number11 of 1995 which is governing the judicial arbitration on civil and commercial articles ${ }^{31}$. The Kuwait legislation provides enough support that incapacity and invalidity is enough grounds for refusing recognition and enforcement of arbitration agreement.

\footnotetext{
${ }^{26}$ (2000)Al-Shareef, N., Enforcement of foreign arbitral awards in Saudi Arabia, Dundee.ac.uk, (2000)

${ }^{27}$ (2011)Gandhi, P., Delhi High Court: The public policy ground for resisting enforcement of foreign awards must be interpreted narrowly, Arbitration.practicallaw.com, (2011)

${ }^{28}$ Panama Convention art. 5.2.

29 Art. V(2)(b) of The New York Convention on the Recognition and Enforcement of Foreign Arbitral Awards provides signatory states the right to refuse recognition or enforcement of an arbitral award if it is contrary to the public policy of that country.

${ }^{30}$ (2007)Harris T.L, "The Public Policy Exception to the Enforcement of International Arbitration Awards Under the New York Convention" Journal of International Arbitration 24(1) (2007) at p10

${ }^{31}$ ( 2012) Although the DIFC Courts are separate from the Dubai Courts, the DIFC Courts enjoy the benefits of an "enforcement protocol" with the Dubai Courts (Dubai Law No 12 of 2004 as amended by Dubai Law No 16 of 2011). This protocol ensures that the Dubai Courts shall ratify and execute DIFC Court judgments without "reconsider[ing] the merits" (Art. 7(3)(c) Dubai Law No 12 of 2004 as amended). Further, because DIFC Court judgments are recognised by the Dubai Courts, parties can, in principle, enforce DIFC Court judgments across the Middle East under the GCC and Riyadh Conventions. One such example has already arisen where a DIFC Court order was recognised in Kuwait (Global Strategies Group (Middle East) FZE v Aqeeq Aviation Holding Company LLC (DIFC Arbitration 002/2010).
} 


\section{References}

1. Barraclough, A., and Waincymer, J., Mandatory Rules of Law In International Commercial Arbitration (2005), MELB.J.Int'1 L. 6 at 210-211

2. Al-Nowaser, K., A legal review on the principle of "The contract is the law of contractors”, Aleqt.com, at http://www.aleqt.com/2011/11/06/article_596219.html (last accessed on Feb 28th 2014)

3. Gandhi, P., Delhi High Court: The public policy ground for resisting enforcement of foreign awards must be interpreted narrowly, (2011)

Arbitration.practicallaw.com,

4. Komninos, A., Recent Development in International Arbitration Around The World, (2006) 2 White and Case Int'l Newsletter 19 at 5-6

5. Park, Arbitration of International Contract Disputes, (2001) supra note 64, at 1787

6. Nicholas Ulmer, Drafting the International Arbitration Clause, (1986) 20 Int'1 Law 1335, at 1342-43

7. International Standard Elec. Corp. v. Bridas Sociedad Anonima Petrolera Industrial y Comercial, (1990) 745 F. Supp. 172, 176-78 (S.D.N.Y. 1990

8. Bowman Routledge, On the Importance of Institutions, Review of Arbitral Awards for Legal Errors, (2003) 19(2) J Int'l Arb 81 (2002).

9. Roy, K., The New York Convention and Saudi Arabia: Can a Country Use the Public Policy Defence to Refuse Enforcement of Non-Domestic Arbitral Awards, (1994) Fordham International Law Journal 18 at 921

10. Kuwaiti Arbitration Code(1980)

11. Kuwaiti Civil and Commercial Procedural law (1980)

12. The New York Convention on the recognition and enforcement of foreign awards of 1958

13. The International Chamber of Commerce Arbitration rules ( 2002)

14. Karam, S., Emaar Properties to appeal lawsuit ruling, Arabianbusiness.com, (2009) at http://www.arabianbusiness.com/emaar-properties-appeal-lawsuit-ruling13830.html

15. Redfren, A. and Hunter, M., International Arbitration (Fifth ed) (Oxford, UK: Oxford University Press, 2009)

16. Commercial Arbitration Centre of the Kuwait Chamber of Commerce and Industry (KCAC) 